ISSN No. 0974-035X

An indexed refereed \& peer-reviewed journal of higher education

Towards Excellence

UGC-HUMAN RESOURCE DEVELOPMENT CENTRE

Gujarat University, Ahmedabad-380009, Gujarat, India

\title{
BHAKTI MOVEMENT IN INDIA AND CONTRIBUTIONS TO GUJARATI BHAKTI POETRY BY NARSINH MEHTA AND GANGASATI
}

\author{
Prof. Ami Upadhyay \\ Dr. Dushyant Nimavat
}

\begin{abstract}
:
The devotional literature we find in India's regional languages is sometimes referred to as Bhakti's literature. Since the poets from Bhakti Panth are more social and cultural, they are more thinkers and more social than literary figures. The translation of classics is particularly meaningful when a native language is translated into English. The classics are introduced to the world. In contemporary Shri Aurobindo and Dilp Chitre did, what Hsuan-tsang did for Sanskrit scripts. A. K. Ramanujan has also made a strong flow of translation in the post-colonial literature and Bhakti has been one of these literatures. This article explores the devotional poems of Narsinh Mehta that are important even in the 21 st century.
\end{abstract}

Keywords: Bhakti Tradition, Bhakti poetry, Narsinh Mehta and Gangasati, Bhajans

Bhakti poems played a major role in regional language development, because they highlighted the everyday language of the people and rejected the Sanskrit elite tradition. Bhakti questioned the caste system, as many of his poets came from the lower castes and the poetry's main theme is that in every individual God is. Some of Tamil was some of the earliest bhakti poetry. Out of the A.D. In 900, with the literature of devotion as the Vachanas, Kannada became an important influence of the saints of different Hindu sects. The mediaeval poets Basavanna and Allama Prabhu are popular Kannada. 
Towards Excellence: An Indexed, Refereed \& Peer Reviewed Journal of Higher Education / Prof. Ami Upadhyay \& Dr. Dushyant Nimavat / Page 105-113

Marathi, Gyaneswar (1200s), the leading author, was the next language to follow bhakti. Eknath and Tuka Ram were other Marathi poets. Narsi Mehta and Premananda were famous poets in Gujarati. The Kashmiri, Bengali, Assamese, Manipuri and Oriya, as well as early Hindi variants were other traditional languages. In the Sant tradition, which believes in an omnipresent Deity, another kind of Bhakti is found. For Hindu Muslim unity Bhakti became a significant forum.

Bhakti Tradition in India is as old as the Vedic and Upanishadic times. It always went hand in hand in hand with spiritual philosophy of Nirguna. In ancient Vedic times, there was no idol worship but the worship of natural elements like Air, Water, Fire and so on. In Upanishadic times, the focus shifted to spirituality emphasizing the presence of the unseen. Upanishadas discussed the formless, abstract power that operate in the entire universe which people called Brahma or Atma. They advised people to undertake journey within. Puranic times shifted the paradigm to Avatars, idol-worship, bhakti and bhajans. Actually, Puranic period can be called the beginning of Bhakti tradition in India.

When we use the word Bhakti, it can be understood as Practical school of philosophical thought or state of consciousness. It is a religious devotion to God either in Saguna form or even Nirguna vision of the Divine. It is a state of pure love for one's concept of God. It aims at the merger of the Bhakta with the Divine. The word Bhakti Yoga refers to the union of the Bhakta with Bhagawan. It also has a systematic process that involves regular practice of chanting the name of the Lord, Puja, attachment and finally resulting into pure love.

The word Bhakti is derived from the Sanskrit root 'bhaj' which means 'to divide, share, and participate, to belong to.' It also means attachment, devotion to, fondness for, faith, love or worship of one's beloved God. Bhakti is a higher form of love that transcend, physical desire and it engage both emotions as well as intellection. It should not be taken as irrational emotion but committed engagement. Bhakti tradition also refers to the devotion of a shishya towards Guru which can be called 'GuruBhakti' Even a highly mystical and profoundly philosophical poet like Kabir says, "Guru Govind Donu khade Kisko Lagu Paay, Balihari Gurudev ki Govind Diyo Batay" (Guru 
Towards Excellence: An Indexed, Refereed \& Peer Reviewed Journal of Higher Education / Prof. Ami Upadhyay \& Dr. Dushyant Nimavat / Page 105-113

and God both stood before me, whom should I bow down ? It was the blessing of the Guru that he showed me Govind (God).

In Indian philosophy, there are three major paths that lead to Moksha- Jnana Marga (the path of knowledge), Karma Marga (the path of action/ work) and Bhakti Marga (the path of Devotion and Love). Bhagawat Purana is an elaborate exposition of Bhakti. It describe nine modes of Bhakti Sravana (listening), Kirtana (Singing), smarana (remembering) padasevan (searving at the feet of the Lord), archana (offering), Vandana (bowing down), dasya (servant hood) sakhya (friendship), atmanivedana (expressing one's emotions). After Bhagawata Purana, there are two major books on Bhakti - Narada purana and Sandilyasutra. Sandilyasutra present Bhakti as the supreme love for one's personal God while Narada Purana calls it profound love for the supreme.

Bhakti poetry is in oral in its origin. It began with great Sanskrit poets and philosophers that composed highly sophisticated poetry in Sanskrit. For example, Adi guru Sankaracharya was primarily a great Vedantin. He was a philosopher par excellence who propagates that Brahma alone was true; the world was nothing but illusion. However, he too turned towards Bhakti by writing great Bhakti poems like Bhavaniastakam or Bhajagovindam.

Devotion to personal God was the distinctive feature of the Bhakti movement. Vaishnavas adored and worshiped Lord Vishnu in his avatars of Lord Rama and Lord Krishna with their consorts Sita and Radha. They emphasized on the chanting of the name (nama) of their personal gods. They worshipped their idol images with elaborate rituals. The Bhakti poets rose above the caste system paving the way for caste equality and gender equality. There were many bhakti poets who belonged to lower castes. Even poets of high caste accepted the fact that love for God cannot be monopolized by any caste, community or gender.

Another important characteristic of Bhakti movement was the use of Vernacular language to compose poems, bhajans, kirtans and songs. Tulsidasa and Kabir used Hindi for their works. Other North India bhakti poets used Avadhi, Bhoja Brija etc. 
Towards Excellence: An Indexed, Refereed \& Peer Reviewed Journal of Higher Education / Prof. Ami Upadhyay \& Dr. Dushyant Nimavat / Page 105-113

Bhakti poets eulogized and glorified God and showed their total surrender to Lord as well as their Guru. They also wrote about the miseries of the illusory world, human fickleness and introspection of self like mystics, they saw oneness in the entire world and nature. They expressed their realization that behind the façade of multiplicity and plurality there is underlying unity, the oneness of the supreme power.

Ramanuja can be considered as a pioneer of Bhakti movement in North India. He acted as a link between the North and South Indian Bhakti movement. Ramananda was the disciple of Ramanuja who revolutionized the entire movement by rejecting caste system and choosing his twelve disciples: Ravidasa from cobbler caste, Pipa from Rajput, Dhanna from Jat, Kabir form weaver, Sena from barber, two women Padmavati and Sursari and five Brahmin disciples Narhariyananda, Sursurananda, Sukhananda, Bhavananda and Anantananda.

Vallabhacharya propagated Krishna worship focusing on the child form of Lord Krishna (Balkrishna). He did not reject luxuries of life but reveled in colorful clothes, celebrations and delicious food. Guru Nanak, Kabir, Mira, Chaitanya were great Bhaktas who contributed immensely to the Bhakti traditions. Kabir tried to bridge Hindu and Islam revolting against the so called rigid and fake pundits of Kashi. Guru Nanak the founder of Sikhism believed in one God (Ek Omkar Sat Naam). Mirabai was a Rajput lady who called Lord Krishna (Girdhar) her husband. She left Mewar and came to Gujarat where she merged with the idol of Dwarkadhish. Chaitanya in Bengal preached the complete faith in Lord Krishna. He focused on singing and dancing to spiritual bliss.

During the Medieval period, the Bhakti Movement in India became a huge river with the merging of various Bhakti traditions from different parts of India. A Sanskrit verse say that Bhakti took birth in Dravidian language, ripened in Karnataka, came to womanhood in Maharashtra and crone like in Gujarat and finally reaching Vrindavana as a fine young woman.

As stated earlier, Bhakti tradition is quite old in India, but it emerged during medieval period across India on a large scale. It emerged chiefly in South India where many 
Towards Excellence: An Indexed, Refereed \& Peer Reviewed Journal of Higher Education / Prof. Ami Upadhyay \& Dr. Dushyant Nimavat / Page 105-113

saintly poets composed songs in the praise of Lord Vishnu. They composed poems in Tamil. There were twelve Alwar poets who belonged to lower castes except one Brahmin and one woman named Andal. In Karnataka and Maharashtra, the Bhakti movement gathered momentum. In Karnataka, the Dasa saints propagated Bhakti as the means of salvation. It also developed Carnatic classical music. Gyaneshwara was a great outcaste Brahmin saint poet of Maharashtra. He composed Gyaneshwari Gita preaching love for all. Namdeva, the tailor saint rejected caste system. Eknath was a Brahmin by birth but he denounced caste discrimination. Tukarama was a shudra shop keeper who wrote abhangas depicting his intense love for Vithoba. Chokhamela was also a Mahar poet whose Abhangas express his servitude to Vithoba calling him Mailbaap.

Narsinh Mehta pioneered Bhakti movement in Gujarat during $15^{\text {th }}$ century. He belonged to high caste Nagar community. He rejected caste system singing and dancing with lower caste people. He said, "Eva Re Ame Eva", (we are as you say) this famous poem 'Vaishnavajan To Tene Re Kahie' portrays the qualities of a true Vaishnava, the man of God. He saya,

"He is a true man of God who understands the suffering of others,

He would help others in need, but no pride ever enters his mind,

He bows down to all in the world never slandering anyone,

He keeps his speech, body and mind stable.

Blessed is the mother of such a man,

He treats all equally, shuns all desires considering other women as mothers.

He never lets his tongue speak a lie and always keeps away from others wealth. 
Towards Excellence: An Indexed, Refereed \& Peer Reviewed Journal of Higher Education / Prof. Ami Upadhyay \& Dr. Dushyant Nimavat / Page 105-113

No attachment and illusions envelope his mind as it houses firm sense of non-attachment

He chants the name of Lord Rama constantly and all holy places reside in his body.

He is free form greed and deceit, lust and anger.

Says Mehta Narsinh, if one sees such a person, seventy-one generation of the person is liberated from the cycle of birth and death."

Mahatma Gandhi adored this poem that epitomises the virtues of a true Harijan, the favourite of God. Though Narisinh Mehta was profoundly spiritual, he did not want to be lost in the dry wilderness of philosophical speculations. He had achieved nonattachment through love of God. For him, the romantic love of Gopis for Lord Krishna epitomizes all the philosophy of the Vedanta. He has experienced non duality of the divine, but he relishes the erotic merger of the Lord with his beloved Radha. He says,

“Akhil Brahmand Ma Ek Tu hari Jujave Roop Anant Bhase"

(You alone, O Hari, is one in the entire universe but you look endless in multiple forms)

He enjoys the multiplicity of the forms of the Divine instead of one abstract, formless Brahma. He says that in this world, brahma dances and plays with Brahma and therefore even what we call Maya is the visible form of the Divine.

Women saint poets have also played an important role in the Bhakti movement. Andal, Mirabai, Akka Mahadevi, Lal Ded, Avvaiyar, Siddheshvari were remarkable female saint poets of India. Bahinabai was a Varkari female saint from Maharashtra. She was the disciple of Tukaram and wrote Abhagas in Marathi dealing with the praise of Vithoba, Atman, Sadguru, devotion and Brahmanhood. Janabai was another female saint from Maharashtra belonging to low caste. She was a disciple of Namdev and wrote over 300 poems depicting the agonies of low caste women in the pursuit on the path of Bhakti. 

Ami Upadhyay \& Dr. Dushyant Nimavat / Page 105-113

Gangasati and Paanbai (19th century) are two female mystic poets from Saurashtra region in Gujarat. Gangasati belonged to Kshatriya tamily. She married to Kahalsang who was also a great devotee of Lord Hanuman and pursed spiritual practice. Paanbai was a young companion of Gangasati wao accompanied her to Gangasati's father-inlaw's house at the time of her marriage. She became an ardent devotee of her spiritual mentor and followed the path of Bhakti and spirituality. All the three Gangasati, her husband and Paanbai composed bhajans which show the philosophical insight of these formally uneducated poets. Kahalsang, Gangasati and Paanbai took Samadhi willingly leaving their physical bodies.

Gangasati composed 52 bhajans that show the depth of her spiritual awakening. She uses day to day images which have made her bhajans quite popular. Though she was born and married in high caste Kshatriya famifamiliy, she was quite revolutionary in her attitude towards caste system. She writes.'

Jatipanu Chhodine Ajati Thavu ne

Kadhavo Varan No Vikar, Jatipanu Nahi Hari Na Deshma ne

Evi Rite Rahevu Nirman Re.

(One must abandon the caste system and become casteless. One must remove the ailment of Varna (caste). There are no castes or distinctions in the land of the lord. One must live without any hankering for honour and reputation.)

Gangasati's very popular bhajan describes the qualities of a Harijan (the devotee of God). She says that even the mountain Meru would move but the mind of a true devotee of God remains unshaken even if the whole universe collapse.Such a person remains touched by joy or sorrow. He keeps busy in Satsang (the company of good people, good thoughts and truth). He remains perpetually happy and without the movement of thoughts in his mind. This poem is like Narsinh Mehta's song about Vaishnavajan. Gangasati focuses more on the equanimity and stability of the mind of the devotee of God. 
Towards Excellence: An Indexed, Refereed \& Peer Reviewed Journal of Higher Education / Prof. Ami Upadhyay \& Dr. Dushyant Nimavat / Page 105-113

In another famous bhajan, Gangasasti describes the traits of a Virtuous Sadhu (Saint). She says that a virtuous saint always lives following the harmony of thought, speech and action. There is always consistency between his thoughts, speech and behavior. $\mathrm{He}$ rises above the name and form connecting with the nameless and formless. He remains in blissful state eternally.

Gangasati uses the word 'Vachan' in her bhajans frequently. Here the word refers to the word, the Name, the silent sound often referred to as Aum. It also refers to the Mantra or the word given by the Sadguru. 'Vachan' has a highly mystical and spiritual significance. It is related to inner harmony of body, mind and soul.

Gangasati says that one must abandon ego and the sense of 'doer'(Karta). When one gives up kartabhava (the sense of the doer of Action), all problems and sufferings end. She says in another popular bhajan that true bhakti is possible with total surrender and humility. A Bhakta has no ego or sense of self as he rises above caste, creed, gender or all kinds of discrimination. The words of Gangasati are profoundly spiritual and appeal to entire humanity. If people rise above caste, creed and leave ego aside, all the problems in the world would end. Her message is highly relevant in the strife-torn world today. 
Towards Excellence: An Indexed, Refereed \& Peer Reviewed Journal of Higher Education / Prof. Ami Upadhyay \& Dr. Dushyant Nimavat / Page 105-113

\section{References}

Eck, Diana and Francoise Mallison. Devotion Divine: Bhakti Traditions from the Regions of India. Paris: Ecole Francaise D’Extreme-Orient, 1991.

Lele, Jayant, ed. Tradition and Modernity in Bhakti Movements. Leiden: E. J. Brill, 1981.

Carman, John B. "Conceiving Hindu 'Bhakti' as Theistic Mysticism." In Mysticism and Religious Traditions, ed. Steven T. Katz. New York: Oxford University Press, 1983.

Narsinh Mehta. Second ed. New Delhi: National Book Trust India, 2001.

Narsinh Mehta. Narsinh Mehtani KavyaKrutiyo (ed.). Shivlal Jesalpura. Ahmedabad:Sahitya Sanshodhan Prakashan, 1989

Kothari, Jayant and Darshana Dholakia.(ed.). Narsinh Padmala. Ahmedabad: Gurjar Granthratna Karyalaya, 1997

Singh, Avadhesh Kumar. Voice of Women - Gargi To Gangasati. D.K. Printworld (P) Ltd., New Delhi 2008

\section{Prof. Ami Upadhyay \\ Professor}

Dr. Babasaheb Ambedkar Open University, Ahmedabad

$\&$

Dr. Dushyant Nimavat

Associate Professor, Gujarat University Ahmedabad 